Maurer School of Law: Indiana University

Digital Repository @ Maurer Law

1975

\title{
NLRB Regulation of Campaign Tactics: The Behavioral Assumptions on Which the Board Regulates
}

Julius G. Getman

Indiana University School of Law

Stephen B. Goldberg

Northwestern University School of Law

Jeanne B. Herman

University of Michigan - Ann Arbor

Follow this and additional works at: https://www.repository.law.indiana.edu/facpub

Part of the Labor and Employment Law Commons

\section{Recommended Citation}

Getman, Julius G.; Goldberg, Stephen B.; and Herman, Jeanne B., "NLRB Regulation of Campaign Tactics: The Behavioral Assumptions on Which the Board Regulates" (1975). Articles by Maurer Faculty. 1908.

https://www.repository.law.indiana.edu/facpub/1908

This Article is brought to you for free and open access by the Faculty Scholarship at Digital Repository @ Maurer Law. It has been accepted for inclusion in Articles by Maurer Faculty by an authorized administrator of Digital Repository @ Maurer Law. For more information, please contact rvaughan@indiana.edu. 


\title{
NLRB Regulation of Campaign Tactics: The Behavioral Assumptions on Which the Board Regulates*
}

\author{
Julius G. Getman $\dagger$ \\ Stephen B. Goldbergf \\ Jeanne B. Herman§
}

The process by which a single union is selected to represent all employees in a particular unit is crucial to the American system of collective bargaining. If a majority vote for union representation, all employees are bound by that choice and the employer is obligated to recognize and bargain with the chosen union. The selection process is controlled by the $\mathrm{Na}$ tional Labor Relations Act, ${ }^{1}$ which applies to almost all nongovernment employees, ${ }^{2}$ and takes place primarily through elections conducted by the National Labor Relations Board. ${ }^{3}$

Typically, union representation elections are preceded by a campaign -much like a political campaign-in which the union tries to persuade employees to vote for union representation and the employer tries to persuade them to vote against it. The Board has developed an elaborate system of rules ${ }^{4}$ to govern campaign tactics:

- This is the first of two articles based on an empirical study of voting behavior in NLRB elections conducted by Professors Getman, Goldberg and Herman. The study was funded by the National Science Foundation and the Russell Sage Foundation. Financial support was also provided by the American Bar Foundation by providing a Visiting Scholarship for academic years I $974-75$ to Professor Goldberg. The basic methodology of the study is set out in Getman, Goldberg \& Herman, The National Labor Relations Board Voting Study: A Preliminary Report, I J. LEG. STUD. 233 (1972). The second article will deal with some of the study's findings. The authors wish to thank Professor Bernard Meltzer, Professor Harry Triandis, Janet and Melvin Kohn, Melvin J. Welles and Robert Williams for their comments on an earlier draft of this Article.

† B.A. I95I, C.C.N.Y.; LL.B. I958, LL.M. I963, Harvard University. Professor of Law, Indiana University.

¥B.A. I954, LL.B. I959, Harvard University. Professor of Law, Northwestern University, Affiliated Scholar, American Bar Foundation.

$\S$ B.A. 1967, Southern Methodist University; A.M. 1969 , Ph.D. 1972, University of Illinois. Assistant Professor of Psychology, University of Michigan.

I. 29 U.S.C. $\$ \$ 141-87$ (1970).

2. 29 U.S.C. $\S \S 152(2)-(3)(1970)$.

3. 29 U.S.C. $\$ \$ 159$ (a), (c) (I) (1970). The largest groups not covered by the National Labor Relations Act are agricultural employees, domestic employees, and employees in industries subject to the Railway Labor Act, 45 U.S.C. $\$ \S 15 \mathrm{I}-88$ (1970). In the decade from 1964-I973, the National Labor Relations Board conducted approximately 85,000 elections, in which over five million workers voted. 38 NLRB ANN. REp. 225 (I973); 37 NLRB ANN. REP. 242 (I972); 36 NLRB ANN. REP. 168 (1971); 35 NLRB ANN. REP. 172 (I970); 34 NLRB ANN. REP. 215 (1969); 33 NLRB ANN. REp. 218 (I968); 32 NLRB ANN. REP. 234 (I967); 3I NLRB ANN. REP. 202 (I966); 30 NLRB ANN. REP. 193 (1965); 29 NLRB ANN. REP. I83 (1964). In 1973 alone, over 9,000 elections took place, with more than one-half million people voting on the question of union representation. 38 NLRB ANN. REP. 225 (I973).

4. These rules have been established by Board case law. The Board possesses authority to 
The Board has said that in election proceedings it seeks to provide a laboratory in which an experiment may be conducted, under conditions as nearly ideal as possible, to determine the uninhibited desires of the employees. [General Shoe Corp., 77 N.L.R.B. 124, 127.] Where for any reason the standard falls too low the Board will set aside the election and direct a new one. Unsatisfactory conditions for holding elections may be created by promises of benefits [International Shoe Co., I23 N.L.R.B. 682], threats of economic reprisals [L.C. Ferguson and E.F. Seggern, $d / b / a$ Shovel Supply Co., r2x N.L.R.B. I485], deliberate misrepresentations of facts by an employer [United States Gypsum Co., I30 N.L.R.B. gor] or a union [The Gummed Products Co., I 2 N.L.R.B. I092], deceptive campaign tactics by a union [Heintz Division, Kelsey-Hayes Co., I26 N.L.R.B. I5I], or by a general atmosphere of fear and confusion caused by a participant or by members of the general public [P.D. Gwaltney \& Co., 7 I N.L.R.B. 37I].5

The Board enforces its rules relating to campaign conduct in two ways. The losing party may file objections to conduct allegedly affecting the outcome of the election; if the Board finds such objections valid, it will set aside the election and order a new one. ${ }^{6}$ Alternatively, the loser may file an unfair labor practice charge, alleging that the winning party has interfered with the right of employees to "bargain collectively through representatives of their own choosing." "Interference with this right constitutes an unfair labor practice which the Board is empowered to remedy by ordering the offending party, employer or union, to cease the forbidden practice. ${ }^{8}$ The Board also possesses the power, if it deems the interference with employee choice sufficiently serious, to order an offending employer to recognize the union as the representative of his employees and bargain with it even though the union lost the election.'

An unfair labor practice almost always will constitute grounds for setting aside the election. ${ }^{10}$ In addition, "[c]onduct that creates an atmo-

promulgate rules under the procedures of the Administrative Procedure Act, but has not done so. See Bernstein, The NLRB's Adjudication-Rule Making Dilemma Under the Administrative Procedure Act, 79 YALE L.J. 57 I (1970).

5. Sewell Mfg. Co., 138 N.L.R.B. 66, 69-70 (I962). See also Modine Mfg. Co., 203 N.L.R.B. No. 77 at Io (May I6, I973) ("We ... have thus opted for safeguards more rigorous than those applied in the arena of democratic procedures which lie at the very heart of our form of government.").

6. The Board's authority to promulgate election rules, and to enforce them by setting aside any election in which they have been violated, was nowhere spelled out in the original National Labor Relations Act, which, in $\S 9$ (c), stated only, "Whenever a question ... arises concerning the representation of employees, the Board may . . certify . . the representatives that have been designated or selected." Act of July 5, r935, ch. $372, \S 9$ (c), 49 Stat. 449 (r935). The Board's power to set aside an election it deems to have been unfairly conducted has, however, long been assumed. See Miami Newspaper Printing Pressmen's Local 46 v. McCulloch, 322 F.2d 993, 997-98 (D.C. Cir. I963), and cases cited therein.

7. 29 U.S.C. $\$ 157$ ( I $_{970}$ ). The power to file such charges is technically open to either party, but it will rarely, if ever, be utilized by the winner.

8. 29 U.S.C. $\$ I 58(a)(I), I 58(b)(x), 160$ (c) (x970).

9. NLRB v. Gissel Packing Co., 395 U.S. 575 (I969). A bargaining order may also be issued when no election has been held. Thus, if the union believes it has little or no chance of winning an election due to the employer's unfair practices, it may prefer to withdraw its election petition and rely solely on unfair labor practice charges to achieve bargaining rights. See id. at 580-8r.

Io. Dal-Tex Optical Co., $x_{37}$ N.L.R.B. 1782, 1787 (1962). 
sphere which renders improbable a free choice will sometimes warrant invalidating an election, even though that conduct may not constitute an unfair labor practice."'I Tactics which fall into this category include those which are thought to impede a reasoned choice, such as misrepresentations of fact or law or appeals to racial prejudice. ${ }^{12}$ The Board thus possesses the power, either through objections proceedings or unfair labor practice proceedings, to regulate a broad spectrum of pre-election conduct.

Board regulation traditionally has been defended by reference to the Board's expert ability to determine which campaign tactics are likely to interfere with employee freedom of choice. The Board has claimed such expertise $^{13}$ and the courts have generally acquiesced in this claim. ${ }^{14}$ In recent years, however, courts and commentators have begun to challenge the assumption of Board expertise, pointing out that the source of the Board's presumed special knowledge has never been identified. Judge Skelly Wright described the Board as "an institution which in over 30 years has itself never engaged in the kind of much needed systematic empirical effort to determine the dynamics of an election campaign or the type of conduct which actually has a coercive impact."15 Moreover, the Board has not required, or even permitted, the introduction of evidence as to whether particular conduct had a harmful impact on the employees involved in a given campaign. ${ }^{16}$ Thus, the Board's findings of unfair labor practices or coercive campaign tactics are not grounded on data as to employee voting behavior, but on assumptions implicit in various Board rules.

II. General Shoe Corp., 77 N.L.R.B. I24, 126 (1948).

12. See R. Williaks, P. Jands \& K. Huhn, NLRB Regulation of Election Conduct 19-25, 93-99 (I974).

13. See, e.g., General Stencils, Inc., 195 N.L.R.B. Irog, IIII (1972), in which the Board set out "to draw upon [its] knowledge and expertise in evaluating the effects of any misconduct ....." In Modine Mfg. Co., 203 N.L.R.B. No. 77 at I5 (May I6, I973), the Board claimed the ability to "take into account the current degree of sophistication of the voters at a particular time or in a particular area of the country." See also General Electric Co., I56 N.L.R.B. 1247, I25I (1966); Peerless Plywood Co., I07 N.L.R.B. 427 (I953).

14. The Supreme Court has stated that the Board can take into account "imponderable subtleties" in weighing the effect of employer speech on employee exercise of the right of self-organization, NLRB v. Virginia Elec. \& Power Co., 3I4 U.S. 469, 479 (I94I), and that the Board is capable of engaging in an "expert estimate as to the effects on the election process of unfair labor practices of varying intensity," NLRB v. Gissel Packing Co., 395 U.S. 575, 612 n.32 (x969). Cf. NLRB v. United Steelworkers Nutone, Inc, 357 U.S. 357, 362-64 (r958); NLRB v. Babcock \& Wilcox Co., 35 I U.S. 105, III-12 (I956); Republic Aviation Corp. v. NLRB, 324 U.S. 793, 798-800 (I945).

15. Getman v. NLRB, 450 F.2d 670, 675 (D.C. Cir. I971). See Getman \& Goldberg, The Myth of Labor Board Expertise, 39 U. CHI. L. REv. 68I (I972). Cf. Bok, The Regulation of Campaign Tactics in Representation Elections Under the National Labor Relations Act, 78 HARv. L. Rev. 38, 46-53, 88-90 (1964); Lewis, Gissel Packing: Was the Supreme Court Right?, 56 A.B.A.J. 877 (1970); Note, Behavioral and Non-Behavioral Approaches to NLRB Representation Cases, 45 IND. L.J. 276 (1970). See also Samoff, NLRB Elections: Uncertainty and Certainty, II 7 U. PA. L. Rev. 228 (I968). An early call for empirical research into the impact of campaign tactics is found in Summers, Politics, Policy Making and the NLRB, 6 SrRACuSE L. REv. 93, 106-08 (I954).

16. "In evaluating the interference resulting from specific conduct, the Board does not attempt to assess its actual effect on employees, but rather concerns itself with whether it is reasonable to conclude that the conduct tended to prevent the free formation and expression of the employee's 
Nothing in the collective activities or experience of the Board insures the accuracy of these assumptions. To be sure, many of the Board's members and staff have spent years interpreting and applying Board rules in light of the policies, language, and legislative history of the National Labor Relations Act. The process of elaborating and harmonizing rules of decision does not, however, provide an understanding of the behavioral validity of the assumptions on which the decisions rest. ${ }^{17}$

The Board lacks any mechanism for determining the actual effect of the tactics used in union representation elections. Empirical studies provide such a mechanism, and some archival and field studies have indicated the potential value of this approach. Unfortunately, past studies have been either narrow in scope, ${ }_{1}^{18}$ carried out by a participant in the elections studied, ${ }^{19}$ or otherwise flawed..$^{20}$ None of them provides the broadly based empirical data necessary to evaluate the effectiveness of campaign tactics used in union representation elections or the propriety of the Board's regulation of those tactics. In an effort to provide the data appropriate for evaluating the validity of the Board's assumptions, we studied 3 I Board elections. In designing the study, it was necessary to identify the behavioral assumptions implicit in Board and court rulings. The article develops those assumptions and compares them to the results of empirical research on voting in political elections, attitude change, and the effects of persuasive communications.

choice." 33 NLRB ANn. REP. 60 (I968). See Shovel Supply Co., xI8 N.L.R.B. 315, 3 I6 (I957). Cf. Modine Mfg. Co., 203 N.L.R.B. No. 77 at I0-14 (May 16, I973). See also Murry Envelope Corp., 130 N.L.R.B. I574, x576 (I96I); Lane Drug Stores, Inc., 88 N.L.R.B. 584, 586 (I950).

17. Some Board members and staft have served as lawyers for employers or unions involved in organizing campaigns, while others have been attorneys in NLRB Regional Offces, engaged in investigating objections and unfair labor practice charges. Neither of these experiences, however, provides more than an impressionistic view of the impact of campaign tactics. As one commentator has pointed out: "The Board's staff consists mostly of lawyers and a few researchers who are primarily concerned with the statistics of the Board's own operations and with legal case analysis. . . . What the Board lacks notably is $(I)$ specific information about labor-management practices and employee attitudes and reactions that may be pertinent to its work, and (2) any systematic means of monitoring the impact of Board and court NLRB doctrines upon industrial practice. . . . Thus, the Board's decisionmaking fails to provide a bridge between Board members ... and the real world of labor relations." Bernstein, supra note 4 , at $577-78$ (footnote omitted).

18. Brotslaw, Attitude of Retail Workers Toward Union Organization, I8 LAB. L.J. I49 (I967); Field \& Field, ". . And Women Must Weep" v. "Anatomy of a Lie": An Empirical Assessment of Two Labor Relations Propaganda Films, I Pepperdine L. Rev. 21 (1973); Comment, An Examination of Two Aspects of the NLRB Representation Election: Employee Attitudes and Board Inferences, 3 Akron L. REV. 2 I 8 (I970).

I9. E.g., San Fernando Valley State College Political Science Department, A Survey of Voters in National Labor Relations Board Elections (unpublished report prepared for the Los Angeles and Orange Counties Organizing Committee, AFL-CIO) (x968).

20. See Getman \& Goldberg, The Myth of Labor Board Expertise, supra note 15, at 691-94 (discussing Pollitt, NLRB Re-Run Elections: A Study, 4I N.C.L. Rev. 209 (1963)); Blackman, Relative Severity of Employer Unfair Labor Practices, 22 LAB. L.J. 67 (I97I). See also Roy, The Role of the Researcher in the Study of Social Conflict: A Theory of Protective Distortion of Response, 24 Human ORGanization 262 (I965). 


\section{The Concept of a Free and Reasoned Choice: An IMplicti Model of Voting Beftavior}

The Board has frequently stated that its objective in regulating the preelection campaign is to protect employee freedom of choice. ${ }^{21} \mathrm{By}$ "freedom of choice" the Board means the opportunity of exercising a "reasoned, untrammeled choice"22 for or against union representation. Board opinions assume that in a properly conducted election, employees will make a "sober and thoughtful choice"23 based on the arguments for and against union representation, reserving their final decision until the campaign ends. In this respect, the Board assumes, or at least seeks to encourage, a model of employee voting behavior similar to that once thought to prevail in political elections; in theory, the political voter attends to the issues and candidates and decides how to vote by weighing the campaign information in light of his own and the country's best interests.

While a campaign preceding a political election is generally free of restrictions on campaign tactics, the Board, explicitly rejecting this aspect of the political analogy, has opted for stringent regulation of campaign conduct. ${ }^{24}$ The decision to regulate closely was a natural outgrowth of the historical circumstances and economic philosophy which led to passage of the National Labor Relations Act. ${ }^{25}$ The decades preceding passage of the Act were marked by stormy efforts to organize employees in major industries. Employers often sought to defeat unionization by capitalizing on their economic power over employees. The techniques employed included mass discharges, yellow dog contracts, and company unions. ${ }^{26}$ In response to the use of such tactics, the framers of the Act, ${ }^{27}$ who sought to "encourage by developing the procedure of collective bargaining, . . . equality of bargaining power, ${ }^{328}$ established unfair labor practice procedures. ${ }^{29}$ They hoped thereby to overcome "the relative weakness of the isolated wage earner." ${ }^{30}$ In this context it was probably inevitable that the Board would reject the model of unregulated political elections and seek to prevent em-

21. See, e.g., General Shoe Co., 77 N.L.R.B. 124, 126 (1948).

22. Seweil Mffg. Co., 138 N.L.R.B. 66, 69 (I962). See R. WIIliasis, P. Jands \& K. Huhn, supra note 12 , at $19-23$.

23. Peerless Plywood Co., 107 N.L.R.B. 427, 429 (1953).

24. Sewell Mfg. Co., I38 N.L.R.B. 66, $69-70$ (I962).

25. See, e.g., Rockford Mitten \& Hosiery Co., I6 N.L.R.B. 501 (r939).

26. See A. Cox \& D. Bok, Cases AND MATterLals ON LABOR LaW, 91-98 (7th ed. 1969).

27. S. REp. No. 573, 74th Cong., Ist Sess. 8-II (r935).

28. Id. at 3 .

29. The framers of the Wagner Act were also concerned with less obvious attempts to use the employer's economic power: "It is impossible to catalog all the practices that might constitute interference, which may rest upon subtle but conscious economic pressure exerted by virtue of the employment relationship." Id. at ro.

30. Id. at 3 . 
ployers from relying upon the threat or use of economic power to influence employee voting decisions. ${ }^{31}$

The Board also assumes that employees need protection from purely emotional appeals if they are to be free to exercise a reasoned choice. ${ }^{32}$ The Board has used the metaphor of "laboratory conditions" to describe the atmosphere necessary for a fair union representation election. ${ }^{33}$ The comparison with a laboratory suggests that an atmosphere of pristine calm and purity is both attainable and necessary to determine the uninhibited desires of the employees. Implicit in the Board's assumption that employees must be protected against emotional appeals is the belief that some employees can make rational choices only in the absence of emotional appeals. If these employees would make non-reasoned choices whether or not emotional appeals are made, then governmental regulation aimed at maximizing the likelihood of a reasoned choice would be a fatuous undertaking.

Thus, the Board has adopted a model of employee voting behavior adapted from the political ideal, while at the same time assuming that this model can be realized in union representation elections only with governmental protection. From these broad assumptions flow the Board's more particularized assumptions. ${ }^{34}$

\section{A. The Assumption That Employees Are Attentive to the Campaign}

Many of the Board's rules presuppose that employees are paying close attention to the campaign. This assumption is perhaps most noticeable in Board cases setting aside elections due to misrepresentations of fact. For example, in Haynes Stellite Co., ${ }^{35}$ the Board set aside the election because the employer made the following statement:

3I. See text accompanying notes $63-85$ infra. Because a union seeking representation rights will not usually possess economic power vis-à-vis the employees involved, elections are rarely set aside on the basis of such power being used improperly. But see NLRB v. Savair Mfg. Co., 414 U.S. 270 (1973), discussed in text accompanying note $\mathrm{I}_{2}$ infra. The economic pressure to accept unionization that is exerted by organizational picketing is regulated by $\S 8(b)(7)$ of the National Labor Relations Act, 29 U.S.C. \$ 158 (b) (7) (1970).

32. In furthering its goal of laboratory conditions, the Board has outlawed such tactics as appeals to racial prejudice, redbaiting, and, on occasion, the showing of films portraying the harmful effects of a strike. See notes $87-89$, II9 infra and accompanying text.

33. The phrase "laboratory conditions" was used first in General Shoe Co., 77 N.L.R.B. I24, I27 (I948), and has been used regularly since that time. See, e.g., Sewell Mffg. Co., I38 N.L.R.B. 66, $69(1962)$.

34. Identifying the Board's assumptions is made difficult by several factors. First, the Board itself rarely articulates them. Second, the Board frequently sets out all the challenged campaign tactics in a case, then asserts that the "totality" of those tactics was such as to interfere with free choice. Cf. Arch Beverage Corp., 140 N.L.R.B. 1385, I387 (1963); Bernstein, supra note I7, at 576. In such cases it is difficult to determine precisely which conduct was objectionable, much less why. Finally, the Board is not consistent; the same assumption is given different weight in different cases and, at times, one assumption is discarded in favor of its opposite. See notes 107-20 infra and accompanying text. Nonetheless, certain assumptions can be identified as more or less central to the Board's regulation of preelection campaign tactics.

35. I36 N.L.R.B. 95, enforcement denied sub nom., Union Carbide Corp. v. NLRB, 3I0 F.2d 844 (6th Cir. 1962$)$. 
[In] some cases we are the sole source of supply at present for some of our customers. We have been told that we would not continue to be the sole source of supply if we become unionized, due to the ever present possibility of a work stoppage due to strikes or walkouts. ${ }^{36}$

One customer had so informed the company, but the Board found that by using "some" instead of "one," the employer had materially misrepresented the facts. ${ }^{37}$ In setting aside the election the Board assumed that employees would distinguish between the use of "one" and "some" and that their vote might be affected by the difference. On other occasions the Board has set aside elections because of a union's misstatement of the wage rates at another firm ${ }^{38}$ and because of an employer's misrepresentation of the amount of union dues that would be required of employees. ${ }^{39}$

Elections will also be set aside when the employer misstates, however slightly, the legal or practical implications of a union victory. For example, an employer may state that a union victory will preclude his dealing directly with employees regarding their wages, hours, or working conditions. However, if his statement implies that employees will be unable to present grievances directly to him, the election will be set aside, since the right to have grievances adjusted without the intervention of the bargaining representative is protected by the first proviso to section 9(a) of the National Labor Relations Act. ${ }^{40}$ Similarly, an employer is free to point out that a strike is possible, indeed likely, if the union wins, but he may not convey the impression that a strike is inevitable. ${ }^{41}$ Here too, the assumption is that employees are attending to the campaign so closely that they will notice the difference. ${ }^{42}$

36. 136 N.L.R.B. at $96-97$.

37. Id. at 97.

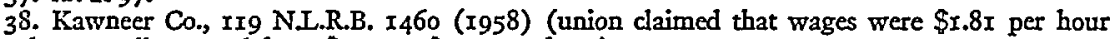
when they actually ranged from $\$$ I.73 to $\$$ r.90 per hour).

39. In Trane Co., I37 N.L.R.B. I506 (I962), the employer deducted an amount from the employee's paychecks which he said was "the estimated amount" of monthly union dues and paid it in a separate envelope. Since the employer deducted five dollars and the union dues were four dollars, the Board found this to be a substantial misrepresentation that constituted partial grounds for setting the election aside. Implicit in this holding is the assumption that some employees would note the amount of money deducted, recall that amount when making their voting decision, and be influenced by that recollection to vote differently than they otherwise would have. The Board sustained the union's objection on the additional grounds that the employer had misrepresented the nature of Tennessee's right-to-work law and that the distribution of literature on the eve of the election had not given the union time to reply.

40. 29 U.S.C. § I59(a) (1970). See Saticoy Meat Packing Co., I82 N.L.R.B. 713, 714-I5 (1970); Winn-Dixie Stores, Inc., I66 N.L.R.B. 227, 234 (1967); Graber Mfg. Co., 158 N.L.R.B. 244, 246-47 (1966).

4r. Unitec Industries, r8o N.L.R.B. 5I, 52-53 (I969); Thomas Products Co., I67 N.L.R.B. 732, 733 (I967).

42. As a corollary of the assumption of attentiveness, the Board assumes that employees will discuss employer actions among themselves. In Great Atlantic \& Pacific Tea Co., I40 N.L.R.B. I33 (1962), the employer operated 16 stores with approximately I20 employees. The area supervisor asked five employees about the merits of unionization. The Board set aside the election, stating: "Individual interviews took place in 25 percent of the total number of stores in the unit. This is hardly 


\section{B. The Assumption That Employees Will Interpret Ambiguous \\ Statements by the Employer as Threats or Promises}

Employers are free to inform employees of their opposition to unionism and frequently do so. ${ }^{43}$ However, when ambiguous statements about the effect of unionism are made by the employer, the Board frequently assumes that employees will infer threats of reprisal or promises of benefit. For example, in Singer $\mathrm{Co}^{44}$ the employer stated that one of his chief reasons for opening a plant in the particular community was to take advantage of lower labor costs. He further stated that costs had risen at other plants after unionization with the result that work had been transferred and nearly I,00o people had lost their jobs. Although the employer's comment could have been interpreted as a legal prediction of the economic consequences of unionization, the Board found the remarks contained an implied threat of reprisal. In Thomas Products Co., ${ }^{45}$ the employer's constant reference to strikes was found not to suggest that union intransigence might cause a strike, but that the employer would take an unyielding bargaining stance, forcing employees to strike to obtain benefits. This statement, too, was seen as a threat of reprisal. In Rein Co., ${ }^{46}$ the employer said that he was not required to negotiate present benefits into a union contract, nor prohibited from telling employees that such benefits could be discontinued. Although these statements were legally accurate, they were found to threaten the loss of existing benefits in retaliation for unionization. ${ }^{47}$

Questions as well as statements may contain implied threats of reprisal or promises of benefit. If the employer tries to find out which employees support the union, the Board assumes that, lacking specific safeguards, his questioning will be understood as a threat of reprisal against union supporters. ${ }^{48}$ If the employer asks employees why they want a union,

an isolated number of interviews, and it is not unreasonable in the circumstances to infer, as we do, that the ramifications of the interviewing technique extended beyond the cmployees immediately involved." Id. at 135 .

43. This freedom is guaranteed by the first amendment and, in unfair labor practice cases, by $\$ 8$ (c) of the National Labor Relations Act, 29 U.S.C. $\$$ I58(c) (I970). Cf. Dal-Tex Optical Co., I37 N.L.R.B. 1782 (1962).

44. I99 N.I.R.B. II95 (1972).

45. I67 N.I.R.B. 732,733 (1967).

46. III N.L.R.B. $537,538-39$ (I955).

47. See also Bok, supra note 15 , at 77-82. The assumption that employer speech will be parsed by the employees for indications of coercion has been applied by the Board even where the employer makes no statement about his reaction to unionization. In Tunica Mfg. Co., I82 N.L.R.B. 729, 74I (I970) (trial examiner's decision, adopted by the Board), the Board held that a company cartoon which showed hands above water grasping for a life preserver with the caption "Don't run the risk" was likely to be considered a threat of retaliation.

48. See, e.g., Isaacson-Carrico Mfg. Co., 200 N.L.R.B. 788, (I972); Spartus Corp., I95 N.I.R.B. I34 (I972); General Automation Mfg., Inc., I67 N.I.R.B. 502 (Ig67); Abex Corp., I62 NI.R.B. 328, 329 (I966); Standard Products Co., I59 N.L.R.B. I59, I69 (I966) (trial examiner's decision, adopted by the Board). The safeguards necessary, in the Board's view, to render interrogation noncoercive are: (I) the employer must communicate his purpose for the interrogation to the employees; (2) the purpose must be legitimate; (3) the employees must be assured there will be no reprisals; 
or what their grievances are, the Board assumes the employees will infer a promise to correct the grievances that prompted the effort to organize. ${ }^{4 \theta}$ Surveillance of union activities is impermissible because it demonstrates the employer's anxiety regarding unionization, thus causing the employees to fear economic retaliation..$^{50}$

\section{The Assumption That Employees Are Unsophisticated About Labor Relations}

Many of the Board's decisions setting aside elections on the basis of employers' statements appear to rest on the assumption that employees know little about labor-management relations or the effect of unionization on such relations, and that nearly all their information on this subject will be a product of the campaign. In Boaz Spinning $\mathrm{Co}^{51}$ the employer set out in some detail the history of other plants (one of which he had operated) that had closed after prolonged strikes called by a union seeking representation rights. He discussed possible results of a strike, including loss of jobs, loss of income, violence, bloodshed, and disruption of family and community life. The Board set aside the election, lost by the union, on the ground that the employer had unfairly given the employees the impression that their only choice was between no union and a strike:

In arguing against unionism, an employer is free to discuss rationally the potency of strikes as a weapon and the effectiveness of the Union seeking to represent his employees. It is, however, a different matter when the employer leads the employees to believe that they must strike in order to get concessions. A major presupposition of the concept of collective bargaining is that minds can be changed by discussion, and that skilled, rational, cogent argument can produce change without the necessity for striking. ... Policy considerations dictate that employees

(4) there must be an overall background free of anti-union hostility. Blue Flash Express, Inc, I09 N.L.R.B. 59I, 593-94 (I954). If the interrogation is characterized as "polling," or systematic interrogation as to union preference, there are additional requirements that the poll be by secret ballot and that its purpose be to determine the truth of a union's claim of majority. Struksnes Construction Co., x65 N.L.R.B. 1062,1063 (1967).

49. See Flight Safety, Inc., 197 N.L.R.B. 223, 227-28 (1972); Reliance Electric Co., I9I N.L.R.B. 44, 46 (I97I); Raytheon Co., I88 N.L.R.B. 3II, 312 (I97I) (concurring opinion); Tom Wood Pontiac, Inc, I79 N.L.R.B. 58I (I969); Tesaco, Inc., I78 N.L.R.B. 434 (1969).

50. Hendrix Mffg. Co. v. N.L.R.B., 32I F.2d 100, 104 n.7 (5th Cir. r963), enforcing r39 N.L.R.B. 397 (1962). Efforts by the employer to determine the identity of union supporters through surveillance of union activities have been held unlawful, even when the employees involved are unaware of such surveillance. Elder-Beerman Stores Corp., I73 N.L.R.B. 566 (I968); Cannon Electric Co., I5I N.L.R.B. 1465, I468-69 (1965); Grower-Shipper Vegetable Ass'n of Central Cal., I5 N.L.R.B. 322, 356 (I939), enforced in part, I22 F.2d 368 (9th Cir. I94I); Bethlehem Steel Corp., ${ }_{4}$ N.L.R.B. 539, 628 (I939), enforced, I20 F.2d 64I (D.C. Cir. I94I). The theory on which secret survillance is forbidden is not that it will directly affect employee free choice, as it obviously cannot, but that it is the first step leading to discriminatory actions against union supporters. Cannon Electric Co., supra at r968-69. While the Board has found secret surveillance to be an unfair labor practice, we are aware of no case in which it has set an election aside solely on the basis of secret surveillance.

5I. I77 N.L.R.B. 788 (1969). 
should not be led to believe, before voting, that their choice is simply between no union or striking. That narrow choice is essentially what this Employer gave them. ${ }^{52}$

Implicit in the Board's decision is the assumption that the employees had not previously considered the possibility of a strike and were unaware of the possible negative consequences of striking. Also implied in the Board's discussion is the assumption that employees will see their choice solely as presented by the employer-no union or strike-and will be unaware that many employers who adamantly oppose unionization ultimately accept a union contract rather than risk a damaging strike. ${ }^{53}$

In Bausch \& Lomb, Inc. $^{54}$ the employer stated that the union seeking to represent the employees "agreed last November that the four [Bausch \& Lomb] employees represented by them will not receive a Christmas bonus. The Union also agreed they will not get the new pension plan." Board set aside the election because the company "created the false impression that the Minneapolis Local gave up the valuable right of the Minneapolis employees to receive the Christmas bonus without receiving anything in return . . . ." In In fact, the union had negotiated for new benefits. The opinion assumes that employees will not know enough about collective bargaining to recognize that existing benefits are generally surrendered in return for other benefits which the union considers more important.

The assumption that employees lack sophistication is also present in the Board doctrine that an employer may not bargain with one union when a rival union claim raises a question concerning representation under the Act. ${ }^{57}$ Bargaining with one union, the Board has said, bestows an "unwarranted prestige" on the recognized union and thereby prevents a free choice by the employees. ${ }^{58}$ The Board's theory must be that substantial prestige will accrue to the recognized union due to its position of authority in the plant. Union leaders will be dealing with management officials with respect to grievances and the negotiation of an agreement; from these dealings the union will acquire an aura of responsibility giving it a significant advantage over rivals in a forthcoming election. This theory presupposes that employees will be so impressed by the union's acting in a responsible role that they will be unable to consider the likelihood that another union could do likewise. Hence, they are deprived of freedom of choice. ${ }^{59}$

52. Id. at 789 .

53. See Ideal Baking Co., $\mathrm{x}_{43}$ N.L.R.B. $546,55 \mathrm{I}-52$ ( $\left.\mathrm{I} 963\right)$. Cf. Utica-Herbrand Tool Div. of Kelsey-Hayes Co., I 45 N.L.R.B. I7I7 (1964).

54. I85 N.L.R.B. 262 (I970).

55. Id. at 264 .

56. $I d$. at 262 .

57. Midwest Piping \& Supply Co., 63 N.L.R.B. I060, ro70 (I945).

58. Scherrer \& Davisson Logging Co., IIg N.L.R.B. 1587 , I 588-89 (1958).

59. See Getman, The Midwest Piping Doctrine: An Example of the Need for Reappraisal of Labor Board Dogma, 3I U. CHI. L. REv. 292, 309 (I964). 
The assumption of unsophistication, even if accurate, could not justify setting aside elections without still another assumption-that the impact of such tactics cannot be neutralized by the union. If the employer threatens to close the plant contingent on a union victory, presumably the union organizer will respond that the employer will not do so as long as the plant is profitable, and that the union has no intention of making it unprofitable. If the employer promises to raise wages contingent on a union loss, undoubtedly the organizer will reply that mere words are not equal to a union contract. If the employer recognizes one union, the other will counter that the favored union is an employer puppet and that the unrecognized union will negotiate a more favorable contract. The Board must assume either that employees will not attend to the union's counterassertions or that the impact of the employer's threatened use of his economic power visà-vis employees is so great that counterassertions will be ineffective. Hence, self-policing of the campaign by the parties is ruled out and governmental regulation is deemed necessary. ${ }^{\text {eo }}$

\section{The Assumption That Free Choice Is Fragile}

The Board assumes that an employee's decision to vote for or against union representation is tenuous and easily altered by the campaign. This assumption is so inherent in Board regulation that it is rarely articulated, save when the Board discusses those tactics it considers particularly effective in unfairly influencing voting. Foremost among these impermissible tactics are threats and acts of reprisal, and promises and grants of benefits. The Board has concluded that such tactics impress employees with the employer's economic power over them and thus interfere with their free choice. This conclusion rests on two further assumptions: (I) unless reminded of the employer's economic power during the campaign, employees will not fully appreciate its meaning or consider the possibility of its exercise; (2) once reminded of that power, employees will be inclined to vote against the union. Implicit in the second assumption is the conclusion that employees otherwise contemplating a vote for union representation will vote against the union either to prevent the employer from exercising his economic power in ways harmful to them or to encourage him to exercise that power in ways favorable to them. Many Board decisions reflect these assumptions.

\section{Threats and acts of reprisal.}

Of all reminders of employer power, threatened or actual loss of employment is considered among the most coercive. In Cornelius American,

60. The rejection of self-regulation is not absolute. The Board stated in Hollywood Ceramics Co., I 40 N.L.R.B. 22I, 224 (I962), that it would not set aside an election despite misrepresentations 
Inc. ${ }^{61}$ the Board held that actual reprisals, even against a single worker, would invalidate an election. ${ }^{62}$ Threats, even when implicit, are also thought to have great impact if the speaker is in a position to effectuate them. Thus, in Thomas Products Co., ${ }^{63}$ the president of the parent company of the employer involved in the election made a speech in which he stated that the operations of the employer had not been successful and that other plants that had not succeeded had been closed, including one which had endured one union turmoil after another. He also told the employees, "I am a businessman and I have to make business decisions." found his comments likely to coerce employees into voting against the union in order to prevent retaliation. The Board's assumptions in setting aside the election were clearly stated:

Power can persuade, and substantial power can persuade substantially. When an employer who controls a multiplant operation stands before employees and verbally juggles the factories, blithely reminding them of his ability to close this, that, or the other one, it is a display of enormous economic power, calculated to put the fear of unemployment in the minds of employees. Such a demonstration is unnecessary to a reasoned discussion of the pros and cons of unionism and can only tend to make employees believe that, should they incur the employer's displeasure, he could easily find a formidable way to express his dissatisfaction. ${ }^{65}$

In General Stencils, Inc. ${ }^{66}$ the Board went a step further and issued a bargaining order based upon a threat of discharge. ${ }^{67}$

\section{Promises and grants of benefits.}

Promises or grants of benefits made to discourage union support are considered exceedingly potent, whether or not made contingent on the union's defeat. For example, the Board stated in Hudson Hosiery Co.: ${ }^{68}$

[T] he presentation of economic benefits to employees in order to have them forego collective bargaining is a form of pressure and compulsion no less telling in its effect on employees because benign. ... . We can perceive no logical distinction between threats to withdraw economic benefits, for the purpose of thwarting self-organization of employees, and promises of better things to come, for the same objective.

What is unlawful under the Act is the employer's granting or announcing

made by the winner unless, inter alia, these misrepresentations are made "at a time which precludes the other party or parties from making an effective reply ...." Apparently, the Board assumes that the impact of misrepresentations on voting choice can be neutralized by counterrepresentations, but the impact of other types of campaign propaganda cannot.

6I. I94 N.L.R.B. 909 (1972).

62. Id. at 920 .

63. I67 N.L.R.B. 732 (1967).

64. Id. at 733 .

65. Id. Cf. Graber Mfg. Co., 158 N.L.R.B. 244, 247-49 (I966).

66. I95 N.I.R.B. II09 (I972).

67. "A direct threat of loss of employment . . . is one of the most flagrant means by which an employer can hope to dissuade employees from selecting a bargaining representative." Id. at rrog.

68. 72 N.L.R.B. 1434 (1947). 
such benefits (although previously determined bona fide) for the purpose of causing the employees to accept or reject a representative for collective bargaining. ${ }^{69}$

Frequently, the grant of benefits is held to exert so powerful an influence on employee free choice that the Board issues a bargaining order on the theory that setting the contaminated election aside and holding another would be futile. ${ }^{70}$

The theory on which promises or grants of benefits are assumed to interfere with rational decisionmaking has never been fully articulated by the Board. In NLRB v. Exchange Parts Co. ${ }^{71}$ the Supreme Court found an implicit threat of reprisals in the bestowal of benefits:

The danger inherent in well-timed increases in benefits is the suggestion of a

fist inside the velvet glove. Employees are not likely to miss the inference that the source of benefits now conferred is also the source from which future benefits must flow and which may dry up if it is not obliged. ${ }^{22}$

The Board has in some cases, by citing Exchange Parts, ${ }^{73}$ suggested a wholly different explanation for treating grants and promises of benefits as illegal. In Texas Transport \& Terminal Co., ${ }^{74}$ the employer threatened reprisals and granted wage increases to discourage union support. The Board commented: "The threats were the stick, the grant of wage increases the carrot."75 The Board's theory in this case would thus appear to be that by granting benefits, the employer is attempting to win favor among employees and to persuade them that they will receive satisfactory wages and working conditions without the assistance of the union. ${ }^{78}$

The vice of a last-minute grant of benefits that attempts to demonstrate that employees do not need a union to assure favorable treatment is by no means clear. One theory on which such conduct might be held unlawful is suggested by the court's statement in Exchange Parts that "[ $t]$ he beneficence of an employer is likely to be ephemeral if prompted by a threat of

69. Id. at I436-37 (footnote omitted). Accord, Bata Shoe Co., II6 N.L.R.B. I239, I24I-42 (I956); Lake Superior Dist. Power Co., 88 N.L.R.B. I496, x498 (I950). As the quoted language indicates, the Board has never distinguished between the promise and the grant of benefits, nor has it distinguished promises of benefits contingent upon a union defeat and promises made in absolute terms. Indeed, even if the employer decides upon the grant of benefits in advance of the campaign for reasons having nothing to do with unionization, their announcement during the campaign will generally constitute an unfair labor practice. Hineline's Meat Plant, Inc., I93 N.L.R.B. 867 (I97I).

70. In issuing a bargaining order in one such case, the Board stated: "There are few unfair labor practices so effective in cooling employees' enthusiasm for a union than the prompt remedy of the grievances which prompted the employees' union interest in the first place." International Harvester Co., 179 N.L.R.B. 753, 753-54 (I969). See also Texaco, Inc., I78 N.I.R.B. 434 (I969), enforced, $436 \mathrm{~F} .2 \mathrm{~d} 520$ (7th Cir. 197I), in which a bargaining order was predicated on an employer's solicitation and adjustment of grievances.

71. 375 U.S. 405 (1964).

72. Id. at 409 (footnote omitted).

73. See, e.g., Hineline's Meat Plant, Inc., I93 N.L.R.B. 867 (r97 I).

74. 187 N.L.R.B. 466 (1970).

75. Id. at 468 .

76. See also Bok, supra note 15, at 113. 
unionization which is subsequently removed." ${ }^{\prime 7}$ In other words, a lastminute grant of benefits for the purpose of discouraging union activity may represent only the employer's response to the immediate prospect of unionization rather than a long-range policy of maintaining a high level of benefits. Because of their assumed lack of sophistication, the employees will be unaware of the ephemeral nature of the last-minute grant of benefits, and hence will be misled into believing that unionization is unnecessary to secure future benefits. ${ }^{78}$

While only those grants of benefit that the employer intends to influence employee voting choice are unlawful, the employer's intent need not be communicated explicitly to the employees in order to have the desired influence. For example, in Texas Transport \& Terminal Co., ${ }^{79}$ the employer decided to give a wage increase during the campaign. The Board found that the timing of the increase was influenced by the campaign. Although the employer did not couple the announcement of the increase with the campaign in any way, the Board assumed that the employees would make the connection on their own. ${ }^{80}$

Even when a change is decided upon for business reasons unrelated to unionization if it is announced during the campaign it is assumed that employees will regard it as a response to their efforts to organize. ${ }^{\mathbf{2 1}}$

\section{Other reminders of employer power.}

The Board's view of the fragility of rational decisionmaking is further demonstrated by cases holding that certain forms of employer campaigning are so potent that they are inconsistent with freedom of choice regard-

77. 375 U.S. at 4 Io. This statement was triggered by the Court of Appeals' suggestion that enforcement of the Board's order would have the "ironic" result of "discouraging benefits for labor." 304 F.2d 368, 376 (5th Cir. 1962).

78. See Bok, supra note I5, at II4. This analysis would be inapplicable to cases such as Hineline's Meat Plant, Inc., I93 N.L.R.B. 867 (I97x), in which the Board relied on Exchange Parts in finding unlawful a last-minute announcement of new benefits which the employer had previously decided to grant for reasons other than to thwart unionism. While the employer was found to have timed the announcement of the new benefits to achieve maximum impact on employee voting behavior, there was little reason to suppose, regardless of the timing of the announcement, that benefits granted for reasons unrelated to the threat of unionization would not survive the employees' decision with respect to unionization.

Still another theory on which a last-minute grant or promise of benefits might be held unlavful is that the employees will be so enthralled by the immediacy of such benefits that they will be unable to put them in proper perspective.

79. I87 N.L.R.B. 466 ( 1970 ).

80. It stated: "In our experience, an employer rarely couples a wage increase intented [sic] to affect employee desires during an organizational campaign with an explicit avowal of such purpose. The absence of such a statement does not make the announcement lawful however. . . . Employees are well able to understand the purpose of well-timed grants of benefit without being told by their grantor that the increases are intended to dissuade them from unionization." Id. at 468 .

81. See Hineline's Meat Plant, Inc., I93 N.L.R.B. 867 (I97I). So, too, the Board assumes that actions detrimental to employees, if taken for the purpose of discouraging unionization, will be understood by them to serve that purpose even if it is not made explicit. See Great Southwest Warehouses, Inc., 183 N.L.R.B. 645,647 (x970). 
less of the content of the statements made. In General Shoe Corp..$^{82}$ the company's general manager and the personnel manager met in their offices with small groups of employees to urge them to vote against the union. Their statements were found to be moderate in tone but the Board still set aside the election because they were made in the "locus of final authority." ${ }^{\text {s3 }}$

Home visits by the employer for the purpose of campaigning against the union are also prohibited. In Peoria Plastics $\mathrm{Co}^{84}$ the Board equated such visits with calling employees into the employer's office individually and concluded that they interfered with free choice, regardless of whether the employer's remarks were coercive. ${ }^{85}$

\section{Interference with free choice unrelated to employer power.}

The freedom of employees to vote for or against union representation is thought to be vulnerable to a variety of campaign tactics that do not trade upon the employer's economic power over the employees, but that nonetheless prevent employees from acting in a rational and nonemotional fashion. All campaign speeches on working time to massed assemblies of employees within 24 hours of the election are prohibited because such speeches "have an unwholesome and unsettling effect and tend to interfere with . . . sober and thoughtful choice." ${ }^{\text {88 }}$

Appeals to racial prejudice, when regarded by the Board as inflammatory, are proscribed because " $[\mathrm{t}]$ hey create conditions which make impossible a sober, informed exercise of the franchise." ${ }^{87}$ Similarly, linking the trade union movement to communism may be a basis for setting aside an election. ${ }^{88}$ Even statements made by outside parties unrelated to the employer or the union may provide a basis for setting aside an election if the

82. 97 N.L.R.B. 499 (195I).

83. Id. at 502. "When rank-and-file employees are brought to the company offices in small groups, they do not deal in 'arm's length' relationship with the company officials they are directed to see. Anti-union opinions, and the suggestion that the employees reject the union, when uttered in that locus of final authority in the plant, take on a meaning and significance they do not possess under other circumstances." Id. See Peoples Drug Stores, Inc., II9 N.L.R.B. 634, 635-36 (1957). But see NVF Co., 210 N.L.R.B. No. 99 at 3-5 (May 20, 1974). The Board also assumes that the impact of the cmployer's statements will be greater when there are few employees present to hear his statements than when there are many, presumably because they will feel more isolated. Tuttle \& Kift, I22 N.L.R.B. 848,849 (1959).

84. II7 N.L.R.B. 545, 547 (1957).

85. Home visits by unions are permissible because the union does not have control over tenure of employment and working conditions. Plant City Welding \& Tank Co., II9 N.L.R.B. I31, I33-34 (1957). The right to engage in home visits for unions is also deemed important because "unions often do not have the opportunity to address employees in assembled or informal groups." Id. at I33.

86. Peerless Plywood Co., ro7 N.L.R.B. 427, 429 (1953).

87. Sewell Mfg. Co., 138 N.L.R.B. 66, 71 ( $x 962)$. A racial message that is truthful, germane and noninflammatory will be allowed. Id. at 70-7I.

88. Universal Mfg. Corp., I56 N.L.R.B. I459, I466 ( 1966 ). 
Board concludes that these statements created an atmosphere in which rational decisionmaking could not take place. ${ }^{89}$

Some rules appear to be based on both the Board's desire to protect its processes and its assumption of the fragility of free choice. Thus, the distribution of a facsimile of an official ballot marked to suggest that the Board endorses a particular choice is grounds for setting aside an election, ${ }^{90}$ as is the addition of a partisan message to an official Board notice entitled "Rights of Employees." ${ }^{\text {"II }}$ Sustained conversation with prospective voters waiting to cast their ballots is prohibited to maintain order in the polling area and to prevent last-minute distraction and pressures on employees so that they may "consult their own consciences without interference."

\section{E. The Assumption That Limited Union Campaigning on Company Premises Is Adequate}

Proceeding from its assumption that the campaign affects voting behavior, the Board has sought to insure that the union has an adequate opportunity to reach employees with its campaign. ${ }^{93}$ It was settled quite early in the administration of the National Labor Relations Act that an adequate union opportunity to communicate requires that employees be free to solicit on behalf of the union during nonworking time on company premises. ${ }^{94}$

It has been more difficult to resolve whether adequacy of union communication requires: (I) that nonemployee organizers be allowed to solicit on company premises and (2) that the union be allowed an opportunity to respond, on company time and premises, to anti-union speeches delivered by the employer on company time and premises (known as "captive audience" speeches). As to both, decisions of the Supreme Court indicate that the appropriate test is whether the employer's refusal to allow union communication on his premises "truly diminishe[s] the ability of the labor organizations involved to carry their messages to the employees" or creates an "imbalance in the opportunities for organizational communication."

89. In Universal Mfg. Corp., id., an election was set aside on the basis of newspaper ads, editorials, a cartoon and a handbill reproduction of that cartoon. The Board stated: "By appealing to the employees' sentiments as civic minded individuals, injecting the fear of personal economic loss, and playing on racial prejudice, the full-page ads, the editorials, the cartoon, and the handbill were calculated to convince the employees that a vote for the Union meant betrayal of the community's best interests. Faced with pressure of this sort, the employees in our opinion were inhibited from freely exercising their choice in the election." $I d$. at 1466 . See Automotive Controls Corp., I65 N.L.R.B. 450, 462 (I967); Monarch Rubber Co., I2I N.L.R.B. 8I, 83 (1958). Cf. P.D. Gwaltney Jr. \& Co., 74 N.L.R.B. 37 I, 378 ( 1947 ).

90. Allied Electric Products, Inc., rog N.L.R.B. I270, 127x-72 (1954).

9I. Rebmar, Inc., I73 N.L.R.B. I434 (x968).

92. Milchem, Inc., r7o N.L.R.B. 362,363 (r970).

93. The employer, through his ability to communicate with employees during working hours, is assumed to possess this opportunity without the need for Board intervention.

94. Republic Aviation Corp., 5I N.L.R.B. II86, Ir95 (I943), enforced, I42 F.2d r93 (2d Cir. 1944), aff'd, 324 U.S. 793 (I945). See Gale Products, I42 N.L.R.B. I246, I249 (I963), enforcement denied, 337 F.2d 390 (7th Cir. 1964).

95. NLRB v. United Steelworkers of America (Nutone, Inc.), 357 U.S. 357, 362-63 (I958). 
While the stated tests appear to pose somewhat different issues-adequacy of union opportunity to communicate as compared to equality of opportunity-the Board's response has been the same. Except in unusual circumstances, such as when employees are isolated because they work on a ship, an inaccessible island, or a resort hotel,$^{96}$ the Board has rejected union demands for access to company premises by nonemployee organizers, whether to solicit generally or to respond to an anti-union speech. ${ }^{97}$ The Board assumes that unions generally have adequate opportunity to present their views to employees by means of employee solicitation on company premises combined with traditional off-premise channels of communication, such as letters, telephone calls, and union meetings. ${ }^{98}$

\section{F. Assumptions About Authorization Card Signing as an Indication of Employee Choice}

Board rules provide that an election will be held only if the union submits evidence that at least 30 percent of the employees wish union representation.99 Accordingly, the union will almost invariably commence its organizing drive by asking employees to sign cards authorizing it to represent them in negotiating with the employer as to wages, hours, and other conditions of employment. ${ }^{100}$

If the union collects authorization cards from a majority of employees, it may, under certain circumstances, obtain an order directing the employer to bargain without first holding an election or even after losing an election. ${ }^{102}$ The Board issues comparatively few such orders, preferring to rely on elections as the prime determinant of employee choice. ${ }^{102}$ Indeed, an

See NLRB v. Babcock \& Wilcox Co., 35x U.S. r05, II3 (1956), in which the Court stated the test for accessibility of nonunion organizers to be whether their exclusion places employees "beyond the reach of reasonable union efforts to communicate with them . ..."

96. Sioux City \& New Orleans Barge Lines, Inc, r93 N.L.R.B. 382, enforcement denied, 472 F.2d 753 (Sth Cir. 1973) (ship); Alaska Barite Co., I97 N.L.R.B. I023 (1972) (isolated island); S \& H Grossinger's, Inc., I56 N.L.R.B. 233 (I965) (resort hotel).

97. See R. WIIlianis, P. Janus \& K. Humn, supra note I2, at 287-90. Such access has been allowed when the employer maintains an unlawfully broad no-solicitation rule, Montgomery Ward \& Co., I45 N.L.R.B. 846,849 (I964), or a broad, but privileged, rule, May Dept. Stores Co., I36 N.L.R.B. 797 (1962).

98. This assumption was reaffirmed in Excelsior Underwear, Inc., 56 N.L.R.B. I236, 124042 (1966), in which the Board ordered employers to provide unions with the names and addresses of employees eligible to vote in pending elections so that the union could communicate with those employces off company premises, and in General Electric Co., 156 N.L.R.B. 1247 (I966), where the Board refused to reconsider its policy of denying equal time for union responses to captive audience speeches stating that it preferred to wait "until after the effects of Excelsior become known." Id. at I25I. The Board did not state how, in the absence of any procedure for gathering data, it proposed to determine the effects of Excelsior. Nor has it since announced its findings as to those effects.

99. 29 C.F.R. $\$$ IOI.I8(a) (I974).

I00. Sce Note, Union Authorization Cards, 75 YALE L.J. 805, 806, 8I 6 (r966).

ror. See note 9 supra and accompanying text. The Board will issue a bargaining order based on a card majority when it finds the employer to have engaged in unfair labor practices of sufficient magnitude that a free and fair election cannot thereafter be held. See generally NLRB v. Gissel Packing Co., 395 U.S. 575, 591-92 (1969).

102. See NLRB v. Gissel Packing Co., 395 U.S. 575, 596 (1969). 
employer who commits no unfair labor practices need not recognize a union that possesses authorization cards signed by a majority of his employees, but may insist on an election. ${ }^{103}$

The Board's treatment of authorization cards as compared to elections is based on the following assumptions: (I) An employee who signs a union authorization card does so because he wishes union representation, unless the solicitor of his signature represents that the sole purpose of the card is to obtain an election. ${ }^{104}$ (2) The decision to sign an authorization card does not involve the same careful, informed consideration as the voting decision. ${ }^{105}$ (3) An employee who does not sign an authorization card does not wish union representation or is uncommitted. ${ }^{106}$

\section{The Board's Inconsistent Application of Its Assumptions}

The Board has not applied its behavioral assumptions in a consistent fashion. For example, the assumption that employees will infer threats or promises from ambiguous statements has sometimes been given great weight, while, at other times, less sensitivity has been attributed to employees. ${ }^{107}$ Thus, in Birdsall Construction $\mathrm{Co}^{108}{ }^{108}$ the employer stated that if the union contract increased costs, "we are certainly, as businessmen, going to have to consider very strongly the necessity of moving our operations."103 The Board held that this would not be interpreted as a threat. ${ }^{110}$

At times, a majority of the Board, wholly as a matter of speculation and with no more factual data than that possessed by a previous majority, has rejected a rule based upon one assumption in favor of a rule based upon a contrary assumption. For example, the Board held at one time that captive

103. Linden Lumber Div,, Sumner \& Co., Igo N.L.R.B. 718 (I97I), aff'd, 95 S.Ct. 429 (I974).

104. See Cumberland Shoe Corp., I44 N.L.R.B. I268, I269 (I963); Englewood Lumber Co., I30 N.L.R.B. 394, 394-95 (I96I); Note, Union Authorization Cards, supra note 100, at 824.

105. This conclusion is implicit in the decision to permit an employer who does not commit unfair labor practices to insist upon an election. Cf. Carson, The Gissel Doctrine: When a Bargaining Order Will Issue, 41 Forphas L. Rev. 85, 88-9r (1972). This assumption may, to some extent, be premised upon a Board feeling that authorization cards are more readily procured by coercion or fraud than are votes. See Note, Union Authorization Cards, supra note roo, at 824-25.

106. The Board has never issued a bargaining order where the union has not had an authorization card majority. The Board thus treats only card signers as counting towards the union majority status.

I07. See C. Morris, The Developing Labor Law, 75 (197I); Swift, NLRB Overkill: Predictions of Plant Relocation and Closure and Employer Free Speech, 8 GA. L. Rev. 77, 96-98 (1973). I08. I98 N.L.R.B. No. 20 (July I8, 1972).

I09. I d. at $\%$.

1 I0. The employer's statements here certainly seem no more threatening than those made by the employer in Thomas Products Co., r67 N.L.R.B. 732 (1967). See notes 63-65 sttpra and accompanying text. On occasion, the Board has also rejected the assumption that discussion of possible future benefits will be interpreted by employees as a promise of benefits in exchange for voting against the union. In Coverall Rental Service, Inc., 205 N.I.R.B. No. I40 (Aug. 3I, 1973), the employer made the following statement with respect to profit-sharing plans: "Your Board of Directors has been considering several of those. . . However, as you probably understand, any improvement or promise of improvement in our profit-sharing plan at this time might be misunderstood to be an unfair labor practice." Id. at 3-4. The Board, in disagreement with its Regional Director, found that the statement did not constitute an implied promise of benefits. 
audience speeches, absent a union opportunity to reply, were unlawful because "printed materials and individual solicitations ... do [not] . . . approach the persuasive power of an employer's oral presentation."111 In Livingstone Shirt $\mathrm{Co}^{112}$ it reversed itself, concluding that unions were not unduly hindered in their organizational activities by being limited to printed materials and individual solicitations while the employer used captive audience speeches. Changing direction again in May Department Stores Co., ${ }^{113}$ the Board stressed the powerful effect of a captive audience speech, dismissing all methods open to the union as "catch-as-catch-can."

One recent example of a reversal in Board law deals with the legality of a union's offer to waive initiation fees for those employees who signed union authorization cards before an election. The Board originally took the position that such waivers interfered with employee free choice on the theory that an employee who had received a waiver would be constrained to vote for the union so as to receive the financial benefits of the waiver. ${ }^{115}$ Subsequently, in DIT-MCO Inc. ${ }^{116}$ the Board reversed itself, concluding that a waiver of initiation fees would not constrain an employee to vote contrary to his desires.

The Board also reversed itself in Litho Press of San Antonio, ${ }^{117}$ holding that showing of the film And Women Must Weep was neither an unfair labor practice nor a sufficient basis for setting aside an election. The film, which vividly portrays strike violence, ${ }^{118}$ had been held unlawful in a series of cases beginning with Plochman \& Harrison-Cherry Lane Foods, Inc..$^{119}$

III. Metropolitan Auto Parts, Inc, I02 N.L.R.B. I634, I636 (1953).

II2. 107 N.L.R.B. 400,406 (1953).

I13. 136 N.L.R.B. 797 (1962).

Ir4. Id. at 80r. Technically, May Department Stores was not a reversal of Livingston Shirt Co., inasmuch as the former dealt with a department store, for which the Board has long had special rules, while the latter involved a manufacturing concern. Nonetheless, the emphasis of the Board's opinion in May was clearly contrary to that in Livingston.

II5. LoBue Bros., Iog N.I.R.B. II82, x183 (I954).

II6. I63 N.L.R.B. IOI9, I02I-22 (I967).

II7. 2 II N.L.R.B. No. I 43 at 3 (June 30 , 1974). 1967).

Ir8. For a fuller description, see Southwire Co. v. N.L.R.B., 383 F.2d 235, 239-40 (5th Cir.

I19. I40 N.L.R.B. 130, 132-33 (1962). Accord Spartus Corp., I95 N.L.R.B. I34 (1972); Hawthorn Co., I66 N.L.R.B. 25 I (I967); Carl T. Mason Co., I42 N.L.R.B. 480, 483 (I963). The theory on which the Board originally viewed the film as interfering with employee free choice, stated briefly in Plochman \& Harrison, supra, was set out in detail in Chairman McCulloch's concurring opinion in Carl T. Mfason Co., stpra, at 485-86 (footnotes omitted): "The use of professionally seripted and acted motion pictures in Board elections is a new tactical device of enormous potential and influence. The motion picture is a much more powerful instrument than the printed or spoken word in arousing emotions and influencing attitudes. Not only is its initial impact greater, it also has a more lasting effect. From their experience in political elections and their reading of newspapers, most people have learned to treat charges, statements, and promises made in political campaigns with a measure of skepticism. They have learned that exaggerations, misstatements, and appeals to prejudice are an inevitable part of such campaigns, and this experience is a help in evaluating propaganda used in Board elections.

"However, the case of motion pictures used as propaganda in electoral campaigns attendant upon Board elections is different. There is no body of similar experience available to the ordinary 
The inconsistent application of its behavioral assumptions reflects the Board's lack of information in two ways. First, absent empirical data, Board members whose beliefs as to the impact of particular conduct differ from those of their predecessors are free to assert their beliefs as fact. Second, Board members who value highly an interest subordinated to another under existing law can vote to change the law, rejecting the assumption on which it rests in favor of a contrary assumption.

To cite but one example, the frequent changes in the law relating to captive audience speeches may reflect different assumptions of new Board members as to the impact of such speeches. More likely, however, the change is due to the different views of new members as to the desirability of employer freedom to campaign against unionization. Those who value this interest highly state that employer speech has a limited impact and that unions have ample opportunity to respond; those who view the employer as an intruder in employee resolution of the question of union representation, or who place a high value on union representation, state the opposite. The behavioral assumptions, then, are frequently rationalizations for conclusions reached on other grounds. Assumptions can be more easily manipulated in this fashion when they do not rest on empirical data. ${ }^{120}$

\section{The Role of The CouRtS}

The courts have tended to defer to the Board's judgment regarding the impact of campaign tactics on employee voting behavior. For example, the Board's assumption that ambiguous statements are likely to be perceived as threats was justified by Judge Learned Hand in NLRB v. Federbush Co.: ${ }^{121}$

Words are not pebbles in alien juxtaposition; they have only a communal existence; and not only does the meaning of each interpenetrate the other, but all in their aggregate take their purport from the setting in which they are used, of which the relation between the speaker and the hearer is perhaps the most important part. What to an outsider will be no more than the vigorous presentation

voter to permit him to evaluate such presentations. Few individuals are able to see behind the impression of authenticity that a skilled director may create by the use of characters, dialogue, and situation. A sophisticated person would probably recognize a film such as 'And Women Must Weep' for what it is, propaganda intended to create antiunion feeling, and will appropriately weigh or discount its one-sided and distorted message. But such films are not meant for sophisticated audiences. I have no doubt that among audiences of working men and women, as well as others, "And Women Must Weep' is emotionally overpowering."

In overruling Carl T. Mason Co., as well as all other decisions holding "And Women Must Weep" to constitute improper interference with employee free choice, the Board did not discuss Chairman McCulloch's behavioral analysis.

xzo. The instability of Board rules controlling campaigning is also a function of the broad language of the statute, which permits Board members to read their own views into the law, and the political nature of the appointive process, which tends to produce Board members ideologically committed to the interests of labor or management. See Bok, supra note 15, at 39-42. For an interesting defense of politically motivated changes in Board rules, see Bernstein, supra note 4, at 574 n.10.

121. I2r F.2d 954 (2d Cir. 194I). 
of a conviction, to an employee may be the manifestation of a determination which it is not safe to thwart. The Board must decide how far the second aspect obliterates the first. ${ }^{122}$

On occasion the courts have taken the metaphor of laboratory conditions more seriously than the Board, holding that the Board should have set aside elections when it has not. This tendency has been particularly pronounced in cases involving alleged union misrepresentations. ${ }^{123}$ In AllisChalmers Mfg. Co. v. NLRB ${ }^{124}$ the union claimed that nine benefits were granted to white-collar employees as a result of the union's success in securing those benefits for production workers. The union's claim was at least arguably true as to eight of these. The Board held that the Union's propaganda was "virtually accurate," but the court held otherwise.

Even if we were to assume that the first eight items, were, as a matter of fact, negotiated for the production and maintenance workers by the Union and passed along to the draftsmen ... item 9 did not go through that process .... If truth is diluted, it is no longer truth. A glass of pure water is no longer pure if a one-ninth part thereof is contaminated, nor is it "virtually" pure. There cannot be "virtually" the truth any more than there can be "virtually" a virgin. ${ }^{125}$

On other occasions the courts have viewed the Board as attributing too great an impact to employer actions. For instance, the Board has held that interrogation as to union sympathies is necessarily coercive unless the employer utilizes various safeguards. ${ }^{126}$ While courts have accepted the Board's basic premise, they have been more willing to find exceptions in particular cases, with some courts treating failure to abide by the Board's safeguards merely as evidence that the interrogation may have had a coercive impact. ${ }^{127}$

In its decisions as to the use of union authorization cards, the Supreme Court has accepted some of the Board's premises, rejected others, and added assumptions of its own. In NLRB v. Gissel Packing Co., ${ }^{128}$ the Court accepted the Board's basic assumptions about the validity of authorization cards as an indication of employee choice. ${ }^{129}$ The Court added two

122. Id. at 957 .

123. R. Williars, P. Janus \& K. Huhn, supra note 12, at 23, attribute this close judicial scrutiny of alleged union misrepresentations to a belief that the Board has treated unions more favorably than employers in applying the "laboratory conditions" standard.

I24. 26r F.2d 6I3 (7th Cir. I958).

125. Id. at 6r6. In Cross Baking Co. v. NLRB, 453 F.2d I346 (Ist Cir. I97x), the union claimed that a competitor's employees had obtained a $\$ .75$ an hour increase under a union contract, when in fact the increase was approximately $\$ .60$ spread over three years. The Board found no substantial misrepresentation; the Court reversed. In Walled Lake Door Co. v. NLRB, 472 F.2d roro (5th Cir. 1973), the union claimed to represent employees at four of the employer's plants, when in fact it represented them at two. The Board dismissed the employer's objection; the court reversed.

126. See note 48 supra and accompanying text:

127. NLRB v. Lorben Corp., 345 F.2d 346, 347 (2d Cir. I965); Bourne v. NLRB, 332 F.2d 47,48 (2d Cir. x964).

128. 395 U.S. 575 (1969).

I29. Id. at 602-03. 
additional assumptions: (I) The employer will have an opportunity to present his side of the unionization issue to employees before they sign cards because the union will inform the employer of its organizing drive early in the campaign. ${ }^{130}$ (2) Card signers are under no greater group pressure to sign and not revoke an authorization card than are other employees to state and not vary from a voting intent. Elections are most often held in small units in which virtually every voter's sentiments can be carefully and individually canvassed both before and after the voting. All employees in such elections are subject to pressures to disclose their voting intent and to vote in accord with that intent. ${ }^{131}$

Additional assumptions relating to union authorization cards were set out in NLRB v. Savair Mfg. Co., ${ }^{132}$ in which the Supreme Court held that a union's offer to waive initiation fees for all employees who sign cards before an election interferes with employee free choice. Here the Court assumed: (I) Some employees who do not wish union representation will sign cards to avoid the initiation fee in the event the union wins the election. $^{133}$ (2) Some card-signers will feel obliged to carry through on their stated intention to support the union, even though they continue to oppose union representation..$^{134}$ (3) Obtaining authorization cards helps the union win the election because the signed cards will be taken by employees to be an indication of the union's support by their fellows; if the amount of this support is not accurately reflected by the cards, employees may be misled into voting for the union. ${ }^{135}$ (4) The "fist in the velvet glove" theory of $E x$ change Parts ${ }^{136}$ applies to the waiver of initiation fees as an inducement to card-signing because " $[t]$ he failure to sign a recognition slip may well seem ominous to nonunionists who fear that if they do not sign they will face a wrathful union regime, should the union win."137

\section{Political Voter Studies and Attitude Change Research}

The Board's assumptions about the influence of campaigning on voter behavior in representation elections are not wholly consistent with the findings of social scientists studying the effects of influence attempts in other settings. Indeed, the Board's central assumption-that the employee voter,

130. The Court predicated this assumption on the union's desire to subject the employer to the unfair labor practice provisions of the Act. "['T] he union must be able to show the employer's arvareness of the drive in order to prove that his contemporaneous conduct constituted unfair labor practices on which a bargaining order can be based if the drive is ultimately successful." Id. at 603 .

I3I. Id. at 604.

I32. 414 U.S. 270 (I973).

I33. Id. at 275 .

134. Id. at $277-78$.

I35. Id. at 277 .

136. NLRB v. Exchange Parts Co., 375 U.S. 405 (1964).

137. NLRB v. Savair Mfg. Co., 4I4 U.S. 270, 28I (I973). 
in weighing the merits of union representation, will attend to and be significantly influenced by the campaigns of the parties-is contrary to the findings of the political voter studies. ${ }^{138}$ Most voters in political elections make their final decision before the campaign. In their study of the 1960 presidential campaign, Lazarsfeld, Berelson and Gaudet found that 50 percent of the voters had made up their minds six months before the election and 75 percent had done so shortly after the candidates were chosen. ${ }^{130}$ Furthermore, the political vote is not determined by a reasoned choice carefully calculated from the candidates' stands on the issues in the immediate campaign, but primarily by ethnic, class, and family influences which predate and transcend the issues. ${ }^{140}$ The implicit model of the omnicompetent citizen who attends to the campaign and carefully weighs alternative positions in the process of making his voting decision is not even an accurate characterization of the political voter. ${ }^{141}$

The empirical studies of political elections have demonstrated overwhelmingly that people have well-formed political predispositions, and that the campaigns are for the most part ineffective in influencing people to vote contrary to those predispositions. The political campaign appears to have two primary effects. For those who make up their minds early, the campaign may provide a rationale for their decision. For those who delay their voting decision, the campaign appears primarily to activate latent predispositions. ${ }^{142}$ Since most political voters make early and firm decisions, investigations of campaign effectiveness have focused on those voters who report themselves to be undecided, or who switch from supporting one candidate to another during the course of the campaign. The research shows that the model of the openminded voter is not an appropriate characterization of the undecided voters; they have fewer opinions on issues and are less likely to participate in election events or expose themselves to political communications than voters whose decisions are made early. ${ }^{143}$ Similarly, the switchers have been found to be "the least interested in the election; the least concerned about its outcome; the least attentive to political material in the formal media of communication; the last to settle upon a vote decision; and the most likely to be persuaded, finally, by a personal contact, not an 'issue' of the election." "144

I38. See Bok, stura note $x_{5}$, at 48 . $1968)$.

139. P. Lazarsfeld, B. Berelsen \& H. Gaudet, The People's Chorce 54 (paperback ed.

i40. Cf. A. Campeeli, P. Converse, W. Mfitler \& D. Stokes, The American Voter 86-87, I84-209 (I964).

I4I. Sears, Political Behavior, in 5 The Handeoor of Social Psychologr 324-37 (G. Lindzey

$\&$ E. Aronson eds., 2d ed. x 969 ).

I42. P. LazARSFedD, B. Beretsen \& H. Gaudet, supra note 139, at 83 .

I 43. Id. at 56 .

I44. Id. at 59 . 
To be sure, results from the political studies may not apply to union representation elections. The employee voter may have a less powerful predisposition for or against union representation than the political voter has for or against the major political parties, a factor that might increase the proportion of initially undecided voters. On the other hand, it is unlikely that employees have no well-formed attitudes regarding their wages, hours, and working conditions. ${ }^{145}$ Moreover, very intense attitudes should be formed by direct experience such as working for the employer who is a party in the election. It is also possible that many employees already have well-formed attitudes toward unions resulting from union membership on previous jobs or information acquired from family members, friends, and the mass media.

The primary distinction between political elections and union representation elections has long been thought to lie in the employees' economic dependence on their employer. ${ }^{146}$ The employer's power to administer sanctions, whether positive or negative, provides him with an effective source of influence. The Board assumes that if an employer invokes his economic power, employees initially favoring union representation will switch and vote against the union. The empirical research on communicator power and influence attempts, however, indicates that achieving behavior change is not always so simple. In order for an influence attempt to be effective, the employee must be exposed to it, understand its meaning, know what behaviors will demonstrate his compliance, and believe that the employer can and will monitor compliance. ${ }^{147}$ The avoidance or selective perception of

I45. The political studies have found that voters become more involved when the issues of the campaign are economic and personally salient. For example, the unexpectedly high political involvement of farmers in the I 956 presidential election has been interpreted as a reaction to economic conditions. A. Camprell, P. Converse, W. Millez \& D. Stokes, stupra note r40, at 220. If the saliency of economic issues leads to increased involvement, one should expect, as is true, higher voting rates in union representation elections than political elections. In fiscal r973, votes were cast by 89 percent of all eligible employees in NLRB elections. 38 NLRB ANN. REP. 24I (1973). But, drawing the parallel further, those people who demonstrate high interest levels form early and stable vote intentions. P. LAzArsfeld, B. Bereisen \& H. GaudeT, sttpra note r39, at 53, 67. They may be more attentive to the campaign, but their high intake of campaign propaganda appears to insulate them from switching, not influence them to switch. It is thus unlikely that the greater salience of the issues to the voters in a union representation election makes the preelection campaign a more significant clement in influencing vote switch than in a political election.

146. Dean Theodore J. St. Antoine has stated: "[E]mployec fear . . t takes this whole question completely outside the area with which we are used to dealing in political elections. . . Think of a man whose whole livelihood is dependent upon a particular job. That is the loss he faces. This factor may vary. I can imagine that in the city of Pittsburgh an employer could make a certain kind of speech, using the language a lawyer has taken out of a book as being approved in past NLRB elections. He might not cause the least bit of fear in the employees listening to that speech. . . . But there are other places in our country where the identical speech would have a totally different impact. Out on the Great Plains, for example, you can get into a little town where one proprietary employer holds sway as economic emperor. In that little town the banker, the newspaper, the sheriff, and the entire community dance to the tune that employer calls. There, fear can be pervasive. . . " SourHwestern Legal Foundation, Proceedings of Eleventr ANNuAL INSTrTute ON LABOR LAV 244-45 (I965). r47. See McGuire, The Nature of Attitudes and Attitude Change, in 3 Tre Handeox of Social Psychology I94-96 (G. Lindzey \& E. Aronson eds., 2d ed. 1969). 
communications which challenge one's opinions is well documented. ${ }^{148}$ Employees who favor union representation may well anticipate that the information in an employer speech or letter will be nonsupportive. Such an influence attempt is likely to be avoided altogether; but if the employee is exposed to it, he may misperceive, suppress, or forget the information. ${ }^{149}$

The research on perceptual distortion also indicates that when a person is exposed to a communication which is discrepant from his own position on an issue, he is likely to see that communication as even more discrepant than it is. ${ }^{150}$ Thus a union supporter might very well interpret an employer's ambiguous statements as implied threats or promises. But the Board's assumption that the union supporter will react to a threat or promise with a vote switch is inconsistent with the studies finding that people tend to reject the source of a communication which is very discrepant from their own position rather than changing their position. ${ }^{151}$ For instance, employer threats of reprisal may be calculated to arouse fear and thus inhibit employees from participating in union activities. But the threat may not be intimidating if the employee rejects the likelihood that the employer will carry out the threat, either because the employer's threat is considered unlawful-he cannot do that-or the employer is seen as making idle threats-he will not do that.

Even if the communication does arouse a very high level of fear, it does not necessarily follow that the influence attempt will be successful. The greatest amount of behavior change may occur with moderate levels of fear. Under conditions of low fear, the pro-union employee may be unaffected by the employer's influence attempt. Under conditions of high fear, the employee may conclude that he needs the union for protection..$^{152}$

One condition which might affect the impact of an employer's influence is the degree to which employees are aware of the employer's intent. Union supporters are likely to be sensitive to the employer's purpose. While such sensitivity might heighten perception of the influence attempt, some studies suggest it might serve to minimize its impact. ${ }^{153}$ The effectiveness of the

148. H.C. Triandis, Attitude and Attitude Change (I97I). Triandis concludes that there is clear evidence of de facto selectivity but that the research suggests selectivity is not a general psychological phenomenon.

I 49. Id. at 156.

150. See McGuire, stpra note 147 , at 222.

I5I. Id. at 223.

152. H.C. TRIANDIS, supra note I48, at I9I-92. This curvilinear relationship between fear arousal and persuasion is controversial, however. One review of the literature concludes that most of the recent studies have found a positive relationship between fear and persuasion. Higbee, Fifteen Years of Fear Arozlsal: Research on Threat Appeals: 1953-1968, Psychologicar Bulz. 426 (1969). Nevertheless, a discriminatorily discharged employee may become a martyr. See Arbie Mineral Feed Co. v. NLRB, 438 F.2d 940, 944 (8th Cir. I97I); NLRB v. Crystal Tire Co., 41o F.2d 916, 920 (8th Cir. 1969); Bol, supra note I5, at 4I.

153. See MicGuire, supra note 147 , at 185 . In the case where the appropriate behavior change is ambiguous or unclear, however, prewarning may clarify what behaviors are appropriate and actually increase the degree of change. 
promised or granted reward should also vary with its value to the employee, the degree to which it is related to the motivation for unionization, and, in the instance of a promise, the perceived likelihood of fulfillment. An employee may interpret a promise in light of previous unfulfilled employer promises and not be influenced. ${ }^{154} \mathrm{Or}$, he may distort the intent of the promise or grant of benefit to support his prior opinion, thinking that if the employer will promise or grant this kind of benefit when a union is only a threat, he would be likely to grant even greater benefits if union representation became a reality. ${ }^{155}$

Still another factor relevant to the effect of an employer influence attempt is the degree to which the employer can and does monitor compliance. ${ }^{158}$ Scrutiny of overt union organizational activity is not difficult, and the employer may seek no more: if overt union activity ceases, union supporters may view the union as ineffective and vote against it. The employer's ultimate goal, however, is to influence voting, which occurs under circumstances most difficult to scrutinize-a secret ballot election conducted by a government agency. The employer's power to bring about the behavior he desires may be significantly lessened by the employees' belief in the secrecy of the ballot-if, that is, they believe the ballot to be secret.

On the other hand, the secrecy of the ballot, even if accepted by employees, may not insulate them against the employer's efforts to influence their group decision. Empirical research indicates that group pressure for compliance will increase when rewards or sanctions are defined so that all members of the group share a common fate. ${ }^{157}$ If employees believe that the employer will reward or sanction the group as a whole based on the election outcome, they may influence each other to vote against union representation. ${ }^{158}$

\section{Conclusion}

The Board's basic assumptions about employee voting behavior, to the extent that they can be discerned from a somewhat inconsistent course of decisions, flow from the view that the employee voter acts on the basis of an informed and reasoned judgment, voting to further his own best interests. $\mathrm{He}$ is attentive to the campaign, from which he receives most of his infor-

154. See id. at $182,195$.

155. One union representative has so stated: "In an effort to defeat the union in organizational campaigns, the companies have given wage increases prior to the representation election. Instead of buying the vote of the youth, it has served only to whet his appetite. He votes for the union more readily, for he is convinced with the power of the union he can do at least twice as well no later than the first week following the election." Speech by M.C. Weston, Jr., Director of United Steel Workers, District 35, Labor Relations Problems Created by the Expectations of Young Workers, 75 L.R.R. 281, 282 (I970).

I56. See McGuire, stipra note 147 , at 194.

I57. Id. at 195 .

I58. Id. 
mation about union-management relationships, and by which he is powerfully influenced. The susceptibility to campaign influence is related to his economic dependence on the employer. As a result of this dependence, he is likely to interpret the employer's statements as containing promises of benefit if he rejects the union or threats of reprisal if he does not. Even if he previously favored union representation, he will react to those promises or threats, or to their effectuation, by voting against the union. The Board has developed rules designed to prevent the employer from trading on his economic strength. The Board also seeks to prevent both employer and union from utilizing emotional appeals deemed capable of interfering with the employee's ability to make a free and reasoned choice.

While the studies of voting in political elections, attitude change, and the effects of persuasive communications raise doubts about the validity of the Board's behavioral assumptions, they are by no means conclusive. Research focused directly on behavior in union representation elections is necessary to determine the validity of the Board's assumptions.

Empirical validation of the Board's behavioral assumption is called for especially in view of the nature of the regulation engaged in by the Board. Many of the questions regarding permissible campaign behavior which come to the Board for decision ultimately turn on a resolution of legitimate competing interests. Balancing those interests can be an exceedingly difficult task, frequently amounting to a value judgment about the strengths of the competing concerns. In the absence of empirical data, there exists a tendency to mask value judgments behind assertions about the impact of campaign tactics on voting behavior. The result is that significant questions of policy are not faced squarely, but dissipate into fruitless contradictory suppositions about impact. The availability of empirical data could serve to bring these policy disputes into the open.

The availability of empirical data on the impact of campaigning will not, of itself, be sufficient to resolve all questions as to the appropriate content and scope of Board regulations. Conduct found not to exercise a significant influence on employee voting behavior may nonetheless be forbidden for other reasons. Attempts to influence employees by threats or promises may be proscribed to serve the symbolic function of demonstrating the existence of a national policy disapproving of such behavior. While current forms of campaigning may not be effective in coercing employees to vote contrary to their desires, the withdrawal of governmental regulation might encourage more vigorous efforts that would be effective. Finally, some of the Board's rules do not rest, to any significant extent, on assumptions as to impact, but on a desire to preserve the appearance of fairness in the Board's election processes.

On the other hand, Board regulation of campaigning is not without 
costs. The Board's caseload has risen dramatically in recent years. ${ }^{159}$ Regulation of election campaigns contributes substantially to this caseload. ${ }^{180}$ Commentators have suggested that the Board's caseload has lowered the quality of its decisions and impaired its overall enforcement of the Act. ${ }^{161}$ The parties, too, pay the costs of governmental campaign regulation, both through the financial burden of litigating election challenges and in the delay and consequent industrial instability that may result before the question of union representation is finally resolved. In determining whether the gains of governmental regulation of campaign conduct justify these costs, the question whether that conduct actually influences voting behavior is clearly relevant. ${ }^{162}$

I59. At the close of fiscal year I973, there were 12,308 cases pending before the Board out of $4 I, 077$ received. $3^{8}$ NLRB ANN. REP. 203 (I973). Comparable figures for I 969 were 9,992 pending cases out of 31,303 received, 34 NLRB ANN. REP. I96 (1969), and for 1965, 8,9II pending cases of 28,025 received, 30 NLRB ANN. Rep. I77 (x965).

160 . In fiscal 1973 , objections were filed in $\mathrm{I}, x_{3} 8$ of 9,660 elections conducted. 38 NLRB ANN. REP. 226, 228 (1973).

I6r. R. Williams, P. Janus \& K. HuHn, supra note 12, at 438; Bok, supra note $\mathrm{I} 5$, at $60-6 \mathrm{r}$; Samoff, supra note $\times 5$, at $238-39$.

I62. A subsequent article will present data bearing on some of the Board's assumptions and a discussion of the implications of the findings for future Board regulation. 